\title{
Tip 1 Diabetes Mellitus Hastalarında Serum Ürik Asit Düzeyinin Değerlendirilmesi ve Ürik Asit Düzeyinin Mikrovasküler Komplikasyonlar ile İlişkisinin İncelenmesi
}

\author{
Murat ÇALAPKULU ${ }^{1}$, Muhammed Erkam SENCAR ${ }^{1}$, İlknur ÖZTÜRK ÜNSAL ${ }^{1}$, \\ Seyit Murat BAYRAM ${ }^{2}$, Davut SAKIZ ${ }^{3}$, Mustafa ÖZBEK ${ }^{1}$, Erman ÇAKAL ${ }^{1}$ \\ 1 Sağlık Bilimleri Üniversitesi, Dışkapı Yıldırım Beyazıt Eğitim Araştırma Hastanesi, Ankara. \\ 2 Nevșehir Devlet Hastanesi, Nevșehir. \\ 3 Mardin Devlet Hastanesi, Mardin.
}

\section{ÖZET}

Tip 1 diabetes mellitus (T1DM) pankreasta bulunan beta hücrelerinin hasarı sonucu gelişen ve insülin eksikliği ile karakterize kronik metabolik bir hastalıktır. Nefropati, retinopati ve nöropati diyabetin bilinen mikrovasküler komplikasyonlarıdır. T1DM hastalarında serum ürik asit (SÜA) düzeyini değerlendiren az sayıda çalışma mevcuttur ve SÜA düzeyinin mikrovasküler komplikasyonlar ile ilişkisi tartışmalıdır. Bu çalıșmada T1DM hastalarında SÜA düzeyini değerlendirmeyi ve SÜA düzeyinin mikrovasküler komplikasyonlar ile ilişkisini incelemeyi amaçladık. Bu çalışma 18 yaşından büyük T1DM tanısı ile takipli 160 hastanın ve 85 sağlıklı kontrolün dosyalarının retrospektif değerlendirilmesi ile yapıldı. T1DM hastalarında kontrol grubuna göre SÜA düzeyi düşük bulundu (p:0.035) ve SÜA düzeyi ile HbA1c arasında negatif kolerasyon saptandı (r:-0.172, p:0.03). SÜA ile kreatinin düzeyi arasında pozitif kolerasyon saptandı (r:0.269, p:0.001). Nefropati gelişen hastalarda SÜA düzeyi diyabet süresinden bağımsız olarak yüksek saptanırken (r2:0.185, p:0.027) nöropati ve retinopatisi mevcut olan hastalarda SÜA yüksekliği bağımsız bir risk faktörü olarak saptanmadı. Sonuç olarak T1DM hastalarında kontrol grubuna göre daha düşük SÜA düzeyi bulunmasına rağmen diyabetik nefropati gelişen hastalarda SÜA düzeyinin yüksek olduğu saptandı. Yüksek SÜA düzeyinin diyabetik nefropati gelişiminde risk faktörü olup olmadığını belirlemek için daha ileri prospektif çalışmalar gereklidir.

Anahtar Kelimeler: Tip 1 Diabetes Mellitus. Ürik Asit. Nefropati. Retinopati. Nöropati.

Evaluation of Serum Uric Acid Level in Type 1 Diabetes Mellitus Patients and Investigation of the Relationship Between Uric Acid Level and Microvascular Complications

\begin{abstract}
Type 1 diabetes mellitus (T1DM) is a chronic metabolic disease that develops due to damage to beta cells in the pancreas and is characterized by insulin deficiency. Nephropathy, retinopathy, and neuropathy are known microvascular complications of diabetes. There are few studies evaluating serum uric acid (SUA) levels in T1DM patients, and the relationship of SUA level with microvascular complications is controversial. In the current study, we aimed to evaluate the SUA level in T1DM patients and investigate the relationship between SUA and microvascular complications. The present study was conducted by retrospectively evaluating the files of 160 patients and 85 healthy controls who followed up with a diagnosis of T1DM over the age of 18. The SUA level was lower in T1DM patients than in the control group (p: 0.035), and a negative correlation was found between the SUA level and HbA1c (r:-0.172, p: 0.03). There was a positive correlation between SUA and creatinine level (r: 0.269, p: 0.001). The SUA level was found to be higher in patients with nephropathy regardless of the duration of diabetes (r2: 0.185, p: 0.027). Elevated SUA level was not found as an independent risk factor in patients with neuropathy and retinopathy. In conclusion, although there was a lower SUA level in T1DM patients than in the control group, SUA level was elevated in patients with diabetic nephropathy. Further prospective studies are required to determine whether elevated SUA level is a risk factor for the development of diabetic nephropathy.
\end{abstract}

Key Words: Type 1 diabetes mellitus. Uric acid. Nephropathy. Retinopathy. Neuropathy.

Geliş Tarihi: 09.Mart.2021

Kabul Tarihi: 09.Nisan.2021

Dr. Murat ÇALAPKULU

Sağlık Bilimleri Üniversitesi,

Dışkapı Yıldırım Beyazıt

Eğitim Araştırma Hastanesi

Ankara.

Tel: 05066110116

E-posta: calapkulumurat89@gmail.com
Yazarların ORCID ID Bilgisi:

Murat ÇALAPKULU: 0000-0002-7445-2275

Muhammed Erkam SENCAR: 0000-0001-5581-4886

İlknur ÖZTÜRK ÜNSAL: 0000-0003-3999-6426

Seyit Murat BAYRAM: 0000-0003-1459-5765

Davut SAKIZ: 0000-0003-1480-888X

Mustafa ÖZBEK: 0000-0003-1125-3823

Erman ÇAKAL: 0000-0003-4455-7276 
Tip 1 diabetes mellitus (T1DM) pankreasta bulunan beta hücrelerinin harabiyeti sonucu oluşan mutlak insülin eksikliğinden kaynaklanan bir hastalıktır. Uluslararası Diyabet Federasyonu'na (IDF) göre dünya çapındaki yetişkin nüfusun \% 8,3'ü diyabet hastasıdır ve bunlarında yaklaşık \% 10'unu T1DM oluşturur ${ }^{1}$. Kontrolsüz ya da iyi tedavi edilmemiş T1DM hastalarında, diyabetin mikrovasküler komplikasyonları olarak bilinen retinopati, nefropati ve nöropati gibi komplikasyonların görülme sıklığı artmıştır. Bu komplikasyonlar, geriye dönüşü olmayan sekeller birakarak hastaların ömrünü kısaltmakta, yaşam standartlarını düşürmekte ve iş gücü kaybına sebep olabilmektedir. Bu komplikasyonların erken tanınması ve gelişiminin önlenmesi hastaların yaşam kalitesini arttırmaktadır. $\mathrm{Bu}$ nedenle T1DM hastaları tanı aldıktan 5 yıl sonra veya puberteden itibaren mikrovasküler komplikasyonlar açısından yılda bir değerlendirilmelidir.

Pürin metabolizmasının son ürünü olan ürik asit ksantinin ksantin oksidaz enzimi ile yıkılması sonucu meydana gelir². Epidemiyolojik çalışmalarda, serum ürik asit düzeyinin (SÜA) hipertansiyon, metabolik sendrom, kronik böbrek yetmezliği ve kardiyovasküler bozukluklarla ilişkili olduğu gösterilmiştir ${ }^{2-5}$. Tip 2 diabetes mellitus (T2DM) hastalarında yapılan çeşitli çalışmalar, yüksek SÜA seviyelerinin hastalığın erken bir prediktörü olarak kullanılabileceğini göstermiştir ${ }^{6,7}$. T1DM hastalarında SÜA düzeyi ile ilgili çalışmaların sonuçları tartışmalıdır ${ }^{5,8-10}$. Mikrovasküler komplikasyon gelişmiş hastalarda SÜA düzeyinin değerlendirildiği az sayıda çalışma mevcuttur ve sonuçlar birbiri ile tutarsızdır ${ }^{5,9,11}$. Bizim bu çalışmada amacımız T1DM hastalarında SÜA düzeyini değerlendirmek ve SÜA düzeyinin mikrovasküler komplikasyonlarla ilişkisini araştırmaktır.

\section{Gereç ve Yöntem}

Çalışmamıza merkezimiz Etik Kurulu'nun 29 Nisan 2019 tarih ve 62/16 nolu etik kurul kararı ile başlandı ve katılımcılardan bilgilendirilmiş onam alındı. Merkezimizde 2017 ile 2019 yılları arasında 18 yaşından büyük T1DM tanısı ile takip edilen 207 hastanın verileri retrospektif olarak tarand1. T1DM tanısı Amerikan Diyabet Derneği'nin kılavuzunda belirlenen tanı kriterlerine göre konuldu ${ }^{12}$. Gebeler, emziren anneler, alkol kullanan hastalar, SÜA düzeyini etkileyen ilaç kullanımı olanlar (allopürinol, diüretikler v.b), gut öyküsü olanlar ve verileri eksik olan hastalar çalışma dışı bırakıldı. Sağlıklı kontrol grubu; herhangi bir hastalığ1 olmayan, merkezimize rutin kontrol için başvuran, tetkiklerinde patoloji saptanmayan ve çalışma grubuna uyumlu olacak şekilde yaş-cinsiyet kriterlerini sağlayan kişilerden seçilmiştir. Uygun kriterleri sağlayan 160 T1DM hastası ile 85 sağlıklı birey çalışmaya dahil edildi. Katılımcıların boy, kilo, vücut kitle indeksi (VKI), diyabet süresi, ve mikro- vasküler komplikasyon durumu hasta dosyalarından elde edildi. Venöz kan örnekleri en az 8-12 saatlik açlığı takiben sabah saat 8:00 ile 09:00 arasında alındı. Kanlar EDTA içeren tüplere ve herhangi bir madde içermeyen, düz biyokimya tüplerine $5 \mathrm{ml}$ olarak konuldu. Serum kreatinin ve ürik asit düzeyi en az 8 saatlik açlıktan sonra otomatik analizör kullanılarak otomatik bir teknikle ölçüldü. HbA1c düzeyi yüksek performanslı sıvı kromatografi (HPLC) yöntemi kullanılarak ölçüldü.

\section{Istatistiksel analiz}

Tüm veriler bilgisayar ortamına aktarılarak istatistiksel analizler için SPSS for Windows, versiyon 21 (IBM Corporation, Armonk, New York, United States) uygulama istatistiksel analiz programı kullanılarak analiz edildi. Değişkenlerin normal dağılım gösterip göstermediği Kolmogorov-Smirnov testi ile değerlendirildi. Kategorik değişkenler sıklık ve yüzde (\%) ile özetlendi. Normal dağılıma sahip devamlı değişkenler ortalama \pm standart sapma (SD) değerler olarak, normal dağılıma sahip olmayan değişkenler ise median (min-max) değerler olarak ifade edildi. Bağımsız gruplarda normal dağılım varsayımın sağlandığı durumda bağımsız örneklem Ttesti kullanıldı. Bu ölçümlerde dağılım varyanslarının homojen olmadığ 1 durumlarda Mann Whitney U testi kullanıldı. Kategorik verilerin incelenmesinde Pearson Ki-kare testi kullanıldı. Değişkenler arasındaki ilişkiler Pearson korelasyon katsayısı ile incelendi. BağımSız değişkenlerin belirlenmesi amacıyla lojistik regresyon analizi yapıldı. İstatistiksel olarak anlamlılık düzeyi $\mathrm{p}<0.05$ olarak belirlendi.

\section{Bulgular}

Çalışma 160 T1DM ve 85 sağlıklı gönüllünün değerlendirilmesi ile yapıldı T1DM hastalarının \%63.8'i (n:102) kadındı ve ortalama yaş $31.5 \pm 9.4$ yıl olarak saptand1. Medyan hastalık süresi 8 (1-32) yil olarak saptand1. Hastaların ve kontrol grubunun demografik verileri ve laboratuvar bilgileri Tablo I'de verilmiştir. Kontrol grubu ile karşılaştırıldığında T1DM hastalarında SÜA düzeyi düşük bulundu (p:0.035) ve SÜA düzeyi ile HbA1c arasında negatif kolerasyon saptand 1 (r:-0.172, p:0.03). SÜA düzeyi ile kreatinin düzeyi arasında pozitif kolerasyon saptand 1 (r:0.269, p:0.001). T1DM hastalarının \%44.3'ünde (n:71) mikrovasküler komplikasyon saptandı. Hastaların \%19.3'ünde (n:31) nöropati, \%13.1'inde (n:21) nefropati, \%11.8'inde (n:19) retinopati saptand. Diyabetik nefropati grubunda diyabet yaşı ve SÜA düzeyi daha yüksek saptandı (Tablo II). SÜA düzeyi ile GFR (glomerüler filtrasyon hizı) arasında negatif kolerasyon saptandı (r:-0.295, p:0.001). Lojistik regresyon analizi 


\section{Tip 1 Diyabet ve Ürik Asit}

sonucunda diyabetik nefropati hastalarında SÜA düzeyi diyabet süresinden bağımsız olarak yüksek saptand $1 \mathrm{r}^{2}: 0.185$, p:0.027). Diyabetik retinopati grubundaki hastalar retinopati gelişmeyen gruba göre daha ileri yaştaydı. Diyabet yaşı ve SÜA düzeyi diyabetik retinopati grubunda daha yüksek olarak saptandı (Tablo III). Yaş, diyabet süresi ve SÜA düzeyini içeren lojistik regresyon analizi sonucunda SÜA düzeyi diyabetik retinopati hastalarında risk faktörü olarak saptanmadı $\left(\mathrm{r}^{2}: 0.310, \mathrm{p}: 0.466\right)$. Diyabetik nöropati grubunda yaş ve diyabet yaşı daha ileriydi (Tablo IV). VKİ diyabetik nöropati grubunda daha yüksek olarak saptanırken SÜA düzeyinde anlamlı bir değişiklik saptanmadı (Tablo IV).

Tablo I. Katılımcıların demografik ve laboratuvar verileri

\begin{tabular}{|c|c|c|c|}
\hline & $\begin{array}{l}\text { T1DM } \\
(\mathrm{n}: 160)\end{array}$ & $\begin{array}{c}\text { Kontrol grubu } \\
(n: 85)\end{array}$ & $p$ \\
\hline Yaş (yıl) & $31.5 \pm 9.4$ & $33.8 \pm 9.2$ & 0.07 \\
\hline Cinsiyet (K/E) & $\begin{array}{c}102(\% 63.8) / 58 \\
(\% 36.2)\end{array}$ & $\begin{array}{c}64(\% 75.3) / 21 \\
(\% 24.7)\end{array}$ & 0.066 \\
\hline $\begin{array}{l}\text { Diyabet süresi } \\
\text { (yıl) }\end{array}$ & $8(1-32)$ & - & - \\
\hline VKi $\left(\mathbf{k g} / \mathrm{m}^{2}\right)$ & $22.6 \pm 3.4$ & $23.9 \pm 2.9$ & 0.172 \\
\hline $\begin{array}{l}\text { Açlık kan } \\
\text { şekeri (mg/dl) }\end{array}$ & $220 \pm 106$ & $85.7 \pm 7.2$ & $<0.001$ \\
\hline HbA1c (\%) & $10.8 \pm 3$ & $5.6 \pm 0.3$ & $<0.001$ \\
\hline $\begin{array}{l}\text { Kreatinin } \\
\text { (mg/dl) }\end{array}$ & $0.78(0.45-8.82)$ & $0.76(0.49-1.17)$ & 0.58 \\
\hline $\begin{array}{l}\text { Ürik asit } \\
\text { (mg/dl) }\end{array}$ & $4 \pm 1.4$ & $4.3 \pm 0.7$ & 0.035 \\
\hline
\end{tabular}

VKİ: Vücut kitle indeksi

Tablo II. Nefropati gelişmiş olan tip 1 diyabetli hastaların özellikleri

\begin{tabular}{|c|c|c|c|}
\hline & $\begin{array}{l}\text { Nefropati } \\
\text { gelişenler } \\
(n: 21)\end{array}$ & $\begin{array}{c}\text { Nefropati gelişme- } \\
\text { yenler } \\
\text { (n:139) }\end{array}$ & $p$ \\
\hline Yaş (yıl) & $32.5(20-50)$ & $29(15-67)$ & 0.544 \\
\hline Cinsiyet (K/E) & $13 / 10$ & $89 / 48$ & 0.538 \\
\hline $\begin{array}{l}\text { Diyabet süresi } \\
\text { (yıl) }\end{array}$ & $13(1-32)$ & $8(1-30)$ & 0.003 \\
\hline VKi $\left(\mathrm{kg} / \mathrm{m}^{2}\right)$ & $22.1(20.7-24)$ & $21.8(16.4-33.2)$ & 0.952 \\
\hline HbA1c (\%) & $11.9(7-14.5)$ & $10(6-18.3)$ & 0.737 \\
\hline $\begin{array}{l}\text { Kreatinin } \\
\text { (mg/dl) }\end{array}$ & $0.92(0.45-8.82)$ & $0.75(0.45-1.2)$ & 0.009 \\
\hline GFR (ml/dk) & $64.6(6.7-88.9)$ & $99.5(66.5-170.1)$ & $<0,001$ \\
\hline Ürik asit (mg/dl) & $4.5(1.5-10.2)$ & $3.7(1.1-6.2)$ & 0.04 \\
\hline
\end{tabular}

VKİ: Vücut kitle indeksi; GFR: Glomerüler filtrasyon hızı
Tablo III. Retinopati gelişmiş olan tip 1 diyabetli hastaların özellikleri

\begin{tabular}{|c|c|c|c|}
\hline & $\begin{array}{c}\text { Retinopati } \\
\text { gelişenler (n:19) }\end{array}$ & $\begin{array}{l}\text { Retinopati } \\
\text { gelişmeyenler } \\
\text { (n:141) }\end{array}$ & $p$ \\
\hline Yaş (yıl) & $40(15-67)$ & $28(18-57)$ & $<0.001$ \\
\hline Cinsiyet (K/E) & $91 / 48$ & $11 / 10$ & 0.538 \\
\hline $\begin{array}{l}\text { Diyabet süresi } \\
\text { (yıl) }\end{array}$ & $15(4-32)$ & $7(1-29)$ & 0.003 \\
\hline VKi $\left(\mathrm{kg} / \mathrm{m}^{2}\right)$ & $23.9(21.4-26.1)$ & $21.6(16.4-33.2)$ & 0.254 \\
\hline HbA1c (\%) & $9.6(7-14.9)$ & $10.5(6-18.3)$ & 0.285 \\
\hline Ürik asit (mg/dl) & $4.4(2.5-9.2)$ & $3.8(1.1-10.2)$ & 0.039 \\
\hline
\end{tabular}

VKİ: Vücut kitle indeksi

Tablo IV. Nöropati gelişmiş olan tip 1 diyabetli hastaların özellikleri

\begin{tabular}{lccc}
\hline & $\begin{array}{c}\text { Nöropati } \\
\text { gelişenler } \\
\text { (n:31) }\end{array}$ & $\begin{array}{c}\text { Nöropati } \\
\text { gelişmeyenler } \\
\text { (n 129) }\end{array}$ & p \\
\hline Yaş (yIl) & $38.7 \pm 11.7$ & $29.5 \pm 7.7$ & $<0.001$ \\
Cinsiyet (K/E) & $24 / 11$ & $78 / 47$ & 0.614 \\
$\begin{array}{l}\text { Diyabet süresi } \\
\text { (yıl) }\end{array}$ & $13(1-32)$ & $7(1-29)$ & $\mathbf{0 . 0 0 2}$ \\
VKi (kg/m²) & $25 \pm 3.5$ & $21.8 \pm 3.1$ & $\mathbf{0 . 0 0 8}$ \\
HbA1c (\%) & $10.6 \pm 2.6$ & $10.9 \pm 3.1$ & 0.681 \\
Ürik asit (mg/dl) & $4.3 \pm 1.6$ & $3.9 \pm 1.3$ & 0.201 \\
\hline VKI: Vücut kitle indeksi & & \\
& & & \\
\hline
\end{tabular}

\section{Tartışma ve Sonuç}

Son yıllarda ürik asit düzeyi ile diyabet ve komplikasyonları arasındaki ilişkiyi inceleyen çalışmalar yayınlanmış olup bu çalışmaların sonuçlarının birbiri ile tutarsız olduğu ve tartışmaların devam ettiği görülmektedir ${ }^{5,9-11,13}$. T1DM hastalarında SÜA düzeyini ve ürik asidin komplikasyonlarla ilişkisini inceleyen az sayıda çalışma mevcuttur. T1DM hastalarında SÜA düzeyi ile azalmış insülin duyarlılığı arasındaki ilişki sağlıklı deneklere göre daha zayıftır. T1DM hastalarında SÜA konsantrasyonlarının azaldığı yapılan çalışmalarda gösterilmiştir ${ }^{14-16}$. Bjornstad ve arkadaşlarının çalışmasında, T1DM hastalarında SÜA düzeyi $(4.6 \pm 0.8 \mathrm{mg} / \mathrm{dl})$ kontrol grubuna $(5.0 \pm 1.0 \mathrm{mg} / \mathrm{dl})$ kıyasla daha düşük bulunmuştur ${ }^{14}$. Erdberg ve arkadaşlarının yaptıkları çalışmada SÜA düzeyi T1DM hastalarında $(4.0 \pm 1.3 \mathrm{mg} / \mathrm{dl})$ kontrol grubuna $(4.3 \pm 1.3$ $\mathrm{mg} / \mathrm{dl})$ kıyasla daha düşük olarak gözlenmiştir ve T1DM hastalarında fraksiyonel ürik asit atılımının daha fazla olduğu saptanmıştır ${ }^{16}$. Bu çalıșmada da literatür ile uyumlu olarak SÜA düzeyinin T1DM hastalarında kontrol grubu ile kıyaslandığında daha düşük olduğu saptanmıştır. Glikozürinin proksimal tübüler disfonksiyona ve ürikozüriye yol açabileceği 
çalışmalarda gösterilmiştir ${ }^{17}$. Hastaların zaman içinde diyabetik hale gelmesi ve kötü glisemik kontrolü olanlarda glukozürinin proksimal tübüllere etkisi sonucu fraksiyonel ürik asit atılımının artması T1DM hastalarındaki düşük SÜA düzeyini açıklayabilir.

T1DM hastalarında SÜA düzeyinin diyabetik komplikasyonlar ile ilişkisini inceleyen çeşitli çalışmalar mevcuttur ${ }^{5,9-11,14}$. SÜA düzeyi ve diyabetik nefropati arasındaki nedensellik ilişkisi hala tartışmalıdır ${ }^{5,9,10}$. FindDiane çalışmasında T1DM hastalarının 7 yıllık takibi sonucunda başlangıç SÜA düzeyi ile diyabetik nefropatinin progresyonu arasında nedensel ilișki olmadığı gösterilmesine rağmen SÜA düzeyi yüksek olanlarda renal hasarın daha fazla olduğu saptanmıştır ${ }^{9}$. Pizarro ve arkadaşlarının yaptıkları ve 1686 tip 1 diyabetik hastayı içeren çalışmada SÜA düzeyi yüksek olan hastalarda HbA1c ve hastalık süresinden bağımsız olarak daha düşük GFR değerleri bulunmuştur. SÜA düzeyi ve GFR arasında negatif kolerasyon gözlenmiş olup SÜA düzeyinde her $1 \mathrm{mg} / \mathrm{dl}$ artış için GFR'de $4.11 \mathrm{ml} / \mathrm{dk}$ azalma saptanmıştır ${ }^{5}$. T1DM'lu adolesanlar arasında yapılan bir çalışma sonucunda yüksek SÜA düzeyinin; cinsiyet, HbA1c ve diyabet süresinden bağımız olarak daha düşük GFR ile ilişkili olduğu gösterilmiştir ${ }^{10}$. Adolesanların sağlıklı kontrol denekleriyle karşılaştırıldığında daha düşük SÜA düzeyine sahip olması ve genellikle hipertansiyon veya dislipidemi gibi diyabetik nefropati gelişimiyle ilişkili başka komorbiditelerinin olmaması SÜA düzeyinin nefropati ile ilişkisini daha iyi ortaya koymakta$\mathrm{d}_{1}{ }^{10}$. Bu çalışmada da literatür ile uyumlu olarak SÜA düzeyi ile GFR arasında negatif kolerasyon saptand 1 ve diyabetik nefropati grubunda SÜA düzeyi daha yüksek bulundu. Bu sonuç bize SÜA düzeyinin diyabetik nefropati gelişimini gösteren yararlı bir prediktör olarak kullanılabileceğini göstermektedir.

T1DM hastalarında SÜA düzeyi ile retinopati ilişkisini inceleyen az sayıda çalışma mevcuttur ${ }^{11,13,18}$. Brezilya'da yapılan çok merkezli bir çalışmada 1644 T1DM hastası incelenmiş olup yaş, hastalık süresi, HbA1c ve SÜA düzeyinin retinopati gelişimi için risk faktörü olduğu saptanmıştır. Bjornstad ve arkadaşlar1nın çalışmasında ise 652 T1DM hastası değerlendirilmiş olup yüksek SÜA düzeyinin diyabetik retinopati gelişimini $1.4 \mathrm{~kat}$, proliferatif diyabetik retinopati gelişimini 2.1 kat arttırdığı saptanmıştır ${ }^{18}$. Bu çalışmaların aksine Danimarka'da yapılan bir çalışmada ise SÜA düzeyi T1DM hastalarında yüksek saptanmasına rağmen yaş ve diyabet süresini içeren çoklu değişken analizlerinde diyabetik retinopati gelişimi için risk faktörü olarak saptanmamıştır ${ }^{13}$. Bu çalışmada da retinopati grubunda yaş, hastalık süresi ve SÜA düzeyi daha yüksek saptandı. Ancak yapılan analizler sonucunda SÜA düzeyinin retinopati gelişiminde bağımsız risk faktörü olmadığı saptandı. Retinopatili hasta sayımızın az olması ve hastaların prospektif izlem verilerinin olmaması bu durumu açıklayabilir.
Diyabetik nöropati ile SÜA düzeyini inceleyen çalışmalar incelendiğinde, diğer mikrovasküler komplikasyonlarla ilgili çalışmalara benzer şekilde birbiri ile çelişen sonuçlar mevcuttur ${ }^{13,19-21}$. T1DM hastalarını içeren ve SÜA düzeyi ile nöropati ilişkisini inceleyen bir çalışmada yüksek SÜA düzeyinin nöropati gelişimi için risk faktörü olmadığı saptanmıştır ${ }^{13}$. Bizim çalışmamızda da nöropati grubunda SÜA düzeyi yüksek saptanmasına rağmen bu fark istatistiksel açıdan anlamlı değildi. Çalışmamızdaki nöropatisi olan hasta sayısının az olması ve literatürdeki tartışmalı sonuçlar nedeniyle T1DM hastalarında SÜA düzeyinin nöropati riski üzerindeki etkisini değerlendirmek için prospektif kohort çalışmalarına ihtiyaç vardır.

$\mathrm{Bu}$ çalışmanın bazı sınırlayıcı faktörleri mevcuttur. Bunlardan ilki çalışmanın retrospektif şekilde yapılmış olması ve mikrovasküler komplikasyon gelişmiş az sayıda hasta içermesidir. Fraksiyonel ürik asit atılımının bilinmemesi ve hastaların uzun dönem takip verilerinin olmaması çalışmanın bir diğer sınırlayıcı faktörleridir.

Sonuç olarak bu çalışmada T1DM hastalarında kontrol grubuna göre daha düşük SÜA seviyeleri bulundu. Mikrovasküler komplikasyonlar incelendiğinde yüksek SÜA düzeyinin sadece nefropati grubunda bağımsız risk faktörü olduğu, nöropati ve retinopati gelişimini etkilemediği saptandı. Bu konuda daha kesin sonuçlara ulaşabilmek daha fazla T1DM hastasını içeren büyük, çok merkezli prospektif çalışmalara ihtiyaç vardır.

\section{Etik Kurul Onay Bilgisi:}

Onaylayan Kurul: Sağlık Bilimleri Üniversitesi Dışkapı Yıldırım Beyazıt Eğitim Araştırma Hastanesi Klinik Araştırmalar Etik Kurulu

Onay Tarihi: 29.04.2019

Karar No: 62/16

Araştırmacı Katkı Beyanı: Fikir ve tasarım: M.Ç.; Veri toplama ve ișleme: M.C.., M.E.S., İ.Ö.Ü., S.M.B., D.S.; Analiz ve verilerin yorumlanması: M.Ç., M.Ö., E.Ç; Makalenin önemli bölümlerinin yazılması: M.Ç.

Destek ve Teşekkür Beyanı: Bu makalede yer alan çalışmalar için finansal destek alınmamıștır.

Çıkar Çatışması Beyanı: Makale yazarlarının çıkar çatışması beyanı yoktur.

\section{Kaynaklar}

1. IDF Atlas 9th edition and other resources [Internet]. [a.yer 28 Kasım 2020]. Erişim adresi: https://www.diabetesatlas. org/en/resources/.

2. Ali N, Perveen R, Rahman S, et al. Prevalence of hyperuricemia and the relationship between serum uric acid and obesity: A study on Bangladeshi adults. PloS One 2018;13(11):e0206850.

3. Remedios C, Shah M, Bhasker AG, Lakdawala M. Hyperuricemia: a reality in the Indian obese. Obes Surg 2012;22(6):945- 


\section{Tip 1 Diyabet ve Ürik Asit}

4. Saito Y, Kitahara H, Nakayama T, Fujimoto Y, Kobayashi Y Relation of Elevated Serum Uric Acid Level to Endothelial Dysfunction in Patients with Acute Coronary Syndrome. J Atheroscler Thromb 2019;26(4):362-7.

5. Pizarro MH, Santos DC, Barros BSV, de Melo LGN, Gomes MB. Serum uric acid and renal function in patients with type 1 diabetes: a nationwide study in Brazil. Diabetol Metab Syndr 2018;10:22.

6. Bhole V, Choi JWJ, Kim SW, de Vera M, Choi H. Serum uric acid levels and the risk of type 2 diabetes: a prospective study. Am J Med 2010;123(10):957-61.

7. Dehghan A, van Hoek M, Sijbrands EJG, Hofman A, Witteman JCM. High Serum Uric Acid as a Novel Risk Factor for Type 2 Diabetes. Diabetes Care 2008;31(2):361-2.

8. Pilemann-Lyberg S, Hansen TW, Tofte N, et al. Uric Acid Is an Independent Risk Factor for Decline in Kidney Function, Cardiovascular Events, and Mortality in Patients With Type 1 Diabetes. Diabetes Care 2019;42(6):1088-94.

9. Ahola AJ, Sandholm N, Forsblom C, Harjutsalo V, Dahlström E, Groop P-H. The serum uric acid concentration is not causally linked to diabetic nephropathy in type 1 diabetes. Kidney Int 2017;91(5):1178-85.

10. Lytvyn Y, Mahmud FH, Daneman D, et al. Association Between Plasma Uric Acid Levels and Cardiorenal Function in Adolescents With Type 1 Diabetes. Diabetes Care 2016;39(4):611-6.

11. Melo LGN, Morales PH, Drummond KRG, et al. Current epidemiology of diabetic retinopathy in patients with type $1 \mathrm{di}-$ abetes: a national multicenter study in Brazil. BMC Public Health 2018;18(1):989.

12. American Diabetes Association. 2. Classification and Diagnosis of Diabetes: Standards of Medical Care in Diabetes-2021. Diabetes Care 2021;44(Supplement 1):S15-33.
13. Pilemann-Lyberg S, Hansen TW, Persson F, et al. Uric acid is not associated with diabetic nephropathy and other complications in type 1 diabetes. Nephrol Dial Transplant 2019;34(4):659-66.

14. Bjornstad P, Snell-Bergeon JK, McFann K, et al. Serum uric acid and insulin sensitivity in adolescents and adults with and without type 1 diabetes. $\mathrm{J}$ Diabetes Complications 2014;28(3):298-304.

15. Nan H, Dong Y, Gao W, Tuomilehto J, Qiao Q. Diabetes associated with a low serum uric acid level in a general Chinese population. Diabetes Res Clin Pract 2007;76(1):68-74.

16. Erdberg A, Boner G, van Dyk DJ, Carel R. Urine uric acid excretion in patients with insulin-dependent diabetes mellitus. Nephron 1992;60(2):134-7.

17. Rodríguez G, Soriano LC, Choi HK. Impact of diabetes against the future risk of developing gout. Ann Rheum Dis 2010;69(12):2090-4.

18. Bjornstad P, Maahs DM, Rivard CJ, et al. Serum uric acid predicts vascular complications in adults with type 1 diabetes: the coronary artery calcification in type 1 diabetes study. Acta Diabetol 2014;51(5):783-91.

19. Yu S, Chen Y, Hou X, et al. Serum Uric Acid Levels and Diabetic Peripheral Neuropathy in Type 2 Diabetes: a Systematic Review and Meta-analysis. Mol Neurobiol 2016;53(2):1045-51.

20. Jiang T-N, Li Y-F, Huo L-L, et al. Association between serum uric acid and large-nerve fiber dysfunction in type 2 diabetes: a cross-sectional study. Chin Med J (Engl) 2019;132(9):1015-22.

21. Hu Y, Li Q, Min R, Deng Y, Xu Y, Gao L. The association between serum uric acid and diabetic complications in patients with type 2 diabetes mellitus by gender: a cross-sectional study. PeerJ 2021;9:e10691. 
